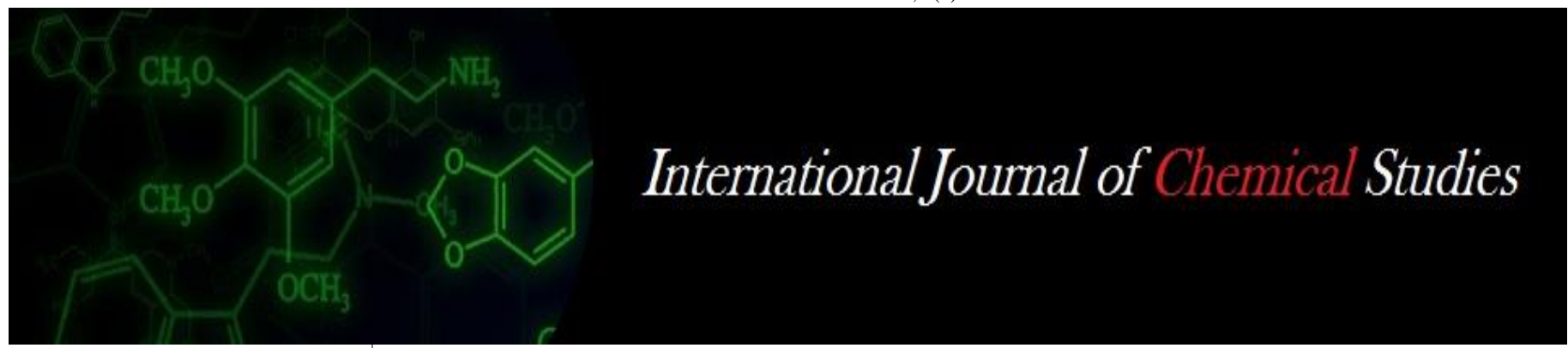

P-ISSN: 2349-8528

E-ISSN: 2321-4902

www.chemijournal.com

IJCS 2020; 8(3): 2896-2901

(C) 2020 IJCS

Received: 19-03-2020

Accepted: 21-04-2020

\section{Jasminkumar Kheni}

Department of Biotechnology,

Junagadh Agricultural

University, Junagadh, Gujarat,

India

Rukam Singh Tomar

Department of Biotechnology,

Junagadh Agricultural

University, Junagadh, Gujarat,

India

\section{Mita Shihora}

Department of Biotechnology,

Junagadh Agricultural

University, Junagadh, Gujarat, India

\section{Shital Padhiyar}

Department of Biotechnology, Junagadh Agricultural

University, Junagadh, Gujarat, India

\section{Hiralben Desai}

Department of Biotechnology, Junagadh Agricultural

University, Junagadh, Gujarat,

India

Tushar Antala

Department of Biotechnology,

Junagadh Agricultural

University, Junagadh, Gujarat,

India

\section{BA Golakiya}

Department of Biotechnology, Junagadh Agricultural

University, Junagadh, Gujarat, India

\section{Protein profiling of chickpea (Cicer arietinum L.) during wilt disease (Fusarium oxysporum f. sp. ciceri)}

\author{
Jasminkumar Kheni, Rukam Singh Tomar, Mita Shihora, Shital \\ Padhiyar, Hiralben Desai, Tushar Antala and BA Golakiya
}

DOI: https://doi.org/10.22271/chemi.2020.v8.i3ap.9652

\begin{abstract}
The proteomic study was carried out in 2DE gel electrophoresis to check differentially expressed proteins during chickpea- wilt interaction in resistance (WR315) and susceptible (JG62) chickpea genotypes. The result of this study showed that total 1070 and 1215 spots were detected in JG-62 and WR-315, respectively. Out of 1070 spots, 480 spots were present in control group while 590 spots were present in wilt inoculated susceptible plants. In resistant group 550 spots were found in control while 665 spots were found in wilt inoculated chickpea. The molecular masses of selected spots were identified with the range of $22.5 \mathrm{KDa}$ to $104.4 \mathrm{KDa}$ with $\mathrm{pH}$ range 4.00 to 6.76 . Many spots were shown the significant level of differential expression in wilt resistant and susceptible chickpea plants. These spots were taken from match area of susceptible variety. Among the \% vol. of each spot were identified and match with each other. Among the 12 spots matches during wilt infection majority shows down regulated as they occupy very low spot area.
\end{abstract}

Keywords: Wilt disease, proteomics, plant-pathogen interaction

\section{Introduction}

Chickpea is known as Bengal gram or garbanzo bean. It complies diploid $(2 n=2 x 6)$ genome size of $738 \mathrm{Mb}{ }^{[1]}$. This genome size is comparatively higher than that of the model legume crops such as soybean, peanut, garden pea, alfalfa, and lentil ${ }^{[2]}$. This genus belongs to the family Leguminoseae and sub-family Papilionaceae. Those are composed of 34 perennial wild species and 9 annual species. Including 9 annual species, chickpea is the only cultivated species ${ }^{[3]}$. Chickpea helps to improve soil fertility in dry lands and fix atmospheric nitrogen. It is one of the major constituents of the Mediterranean diet and a basic food in Asiatic countries [4]. Due to its high nutritional value, its grain international market is very active. The Chickpea is a good and cheap diet source with high protein quantity for people of developing countries; those are largely vegetarian. There are deluge of breeding efforts have contributed towards improvement of chickpea yield, however the lack of stable production is a major concern for the crop adoption farmers ${ }^{[5]}$. Due biotic and abiotic stresses that drastically affect grain yield, especially fungal infectious diseases like: Fusarium wilt, Ascochyta blight and drought or cold stresses.

In this present studies we revealed proteomics associated with chickpea-wilt interaction through two dimensional electrophoresis (2DE). This technique is efficient to identify differentially expressed proteins involved in wilt-chickpea interaction ${ }^{[6]}$. Most of studies of proteomics are performed based on model plant species such as Arabidopsis thaliana [7]. However, research based on model organisms requires experimental authentications. Furthermore, some features and processes are differing in commercial crops. Hence, it is apparent that it is difficult to approach via model plant in totality ${ }^{[8]}$.

This study aims to conclude proteomic basis of wilt disease susceptibility and resistance by two controversial genotypes named JG62 and WR315, respectively. There are many proteins differentially regulated in both resistant and susceptible genotype of chickpea at before and after inoculation with foc.

\section{Corresponding Author:} Jasminkumar Kheni Department of Biotechnology, Junagadh Agricultural University, Junagadh, Gujarat, India 


\section{Materials and Methods}

Plant growth and fungal treatment

Chickpea (Cicer arietinum L.) genotypes JG62 (wilt susceptible) and WR315 (wilt resistant), obtained from Pulse research station of Junagadh Agricultural University (JAU), Junagadh, India were used for experimental analysis. Seeds of both genotypes were grown in a soil sand mixture with conditions of 22 to $28{ }^{\circ} \mathrm{C}, 35$ to $40 \%$ relative humidity and 16 $\mathrm{h}: 8 \mathrm{~h}$ photoperiod of day and night, respectively ${ }^{[9]}$. Plants of both genotypes were grown on normal soil without infection served as control. Both control and infected plants were kept under same growth conditions. Root samples from control and infected plants at 2 day after inoculation (dai) were harvested, instantly frozen in liquid nitrogen and stored at $-80{ }^{\circ} \mathrm{C}$ for further experiments. Proteins were extracted from root colar tissues of each sample.

\section{Protein Extraction and 2D electrophoresis}

Protein precipitation was based on the TCA method with some modification ${ }^{[10]}$. As well GE health care guideline was used when ever needed. Brief, Chickpea root collar tissue was finely powdered in liquid nitrogen with a pre-cooled ceramic mortar and pestle. The resulting powder was suspended in 500 $\mu \mathrm{l}$ cool rehydration buffer (8M Urea, 2\% CHAPS, $7 \mathrm{mg}$ of DTT $/ 2.5 \mathrm{ml}$ buffer) Once it is finely homogenized, the volume is made up to $1.5 \mathrm{ml}$. The mixture was incubated at Room temperature for 10 minute. Centrifuge the mixture at 12000rpm for 30 minute. Take supernatant $500 \mu \mathrm{l}$ and add $10 \%$ TCA in acetone allow precipitation of protein at $-20{ }^{\circ} \mathrm{C}$ for overnight. Next day centrifugation at $12000 \mathrm{rpm}$ for 15 min at $4{ }^{\circ} \mathrm{C}$, the protein pellet was washed four-five times with chilled $90 \%$ acetone. After centrifugation at $12000 \mathrm{rpm}$ for 15 min between rinses, the supernatant was discarded and the pellet was subjected to air dry. The dried powder was solubilised in lysis buffer (8M urea, 2\% CHAPS, 2\% ampholyte pH 4-7(GE Healthcare Bio-Science, Little Chalfont, UK), $0.2 \%$ DTT, $10 \mu \mathrm{l} / \mathrm{ml}$ Protease inhibitor mix). This is then stored overnight at $4{ }^{\circ} \mathrm{C}$ for protein extraction. Then protein was loaded onto isoelectrofocusing (IEF) polyacrylamide gels (IGP Strip) with rehydration or by cup loading method. IEF was carried out on GE healthcare instruments.

The analysis was carried out on 2D protocol was followed as per GE health care standard method with some manual changes ${ }^{[11,12]}$. The $24 \mathrm{~cm}$ IGP strips were rehydrated in rehydration buffer (8M Urea, 2\% CHAPS, 1\% Bromophenol Blue, 0.5\% IGP buffer ( $\mathrm{pH} 4-7$ ), $7 \mathrm{mg}$ DTT per $2.5 \mathrm{ml}$ rehydration solution at time of use) for at least 10-20 h in 400 $\mu l$ rehydration buffer based on length of strips. The sample was loaded using cup loading method and sealed with mineral oil. The separation of protein in this method is based on the size of the protein molecules ${ }^{[13]}$. The SDS PAGE separation was followed by IEF completion. The gel was stained in Coomassie brilliant blue G 250 and distained using methanol, acetic acid and distilled water in ration 40:10:50.

\section{Spot identification and analysis:}

When the tracking dye reached the end of the running gel after complete separation of molecules, power supply was turned off. The gel was gently removed from the space between the plates, immersed in staining solution contained in a tray. After sufficient incubation period, the gel was distained by adding the detaining solution followed by Scanning of gel by Typhoon FLA Scanner. Differentially expressed spots were calculated and identified using Platinum
Master software (GE healthcare). The graphical representation 2DE protocol is given in Figure 1.

\section{Results and Discussion \\ Protein Profiling by 2D Gel Electrophoresis}

Wilt resistant and wilt susceptible chickpea (Cicer arietinum L.) genotypes JG-62 and WR-315 was selected for the study of protein profiling. These both genotypes were selected for wilt inoculation. The samples were collected at 2 dai of Fusarium inoculation to plants and same genotypes with uninoculated. The root collar tissues were selected for protein extraction and 2D-gel electrophoresis.

The Samples were collected after 2 days after inoculation from wilt resistant and wilt susceptible chickpea plant variety. The protein was extracted for 2D gel electrophoresis analysis from fresh root collar of control and wilt inoculated resistant (WR-315) and susceptible (GJ-62) genotypes. Proteins were separated on the basis of their isoelectric point (pI) on the IPG

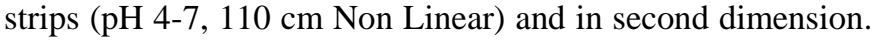
SDS-PAGE was stained with CBB G-250 and stained gel was shown in Figure 2. The result of study showed that total 1070 and 1215 spots were detected in JG-62 and WR-315, respectively. The gel was analyzed using $2 \mathrm{D}$ gel analysis software. Out of 1070 spots, 480 spots were present in control group while 590 spots were present in wilt inoculated susceptible plants. In contrast, resistant group 550 spots were found in control and 665 spots were found in wilt inoculated chickpeas. As compared to resistant control group, there were 115 more spots were preset in wilt inoculated chickpeas. Total 60 spots were matched in susceptible genotypes; and in resistant total 112 spots were matched. The match ID was given from 0 to 112 and 0 to 60 . From which total 45 spots were shown which contain higher area. The match criteria were selected as per volume (\%), PI, CV and molecular masses. The details of spots are given in Table 1 for susceptible group and in Table 2 for resistant group. The different levels of protein expression were showed by the histogram of both resistant and susceptible genotypes Figure 3 and 4 . The molecular masses of selected spots were identified with the range of $22.5 \mathrm{KDa}$ to $104.4 \mathrm{KDa}$; with $\mathrm{pH}$ ranged 4.00 to 6.76 . Among Total matched spots, 12 spots mentioned table 1 . They were significantly differentiated with expression level between two treatment groups. The volume of each spot was identified and match with each other. Total 12 spots matched during wilt infection majority shows down regulated as they are occupy very low volume while in wilt resistant chickpea they show higher and up regulation among the 12 selected spots. The green area is matched area and it's significantly increase in infected WR-315 plants. It indicates that major up-regulation of proteins related to defense and signaling molecules. The similar study of protein expression in 2D gel electrophoresis founds in chickpea and soybean and further expressed protein were identified for disease resistant $[14,15]$. A study also revealed that up regulated proteins involved in disease resistance while down regulated proteins involved in amino acid metabolism and photosynthesis ${ }^{16}$. Another study carried out on DIGE analysis indicates that 47 differentially expressed proteins involved in of salt- and drought mechanisms ${ }^{[17]}$. Alternatively, Rollins et al. (2013) performed leaf proteome alterations in the context of physiological and morphological responses to drought and heat stress in barley (Hordeum vulgare L.) ${ }^{[18]}$. Proteomics of salinity stressed in wheat chloroplasts revealed that antioxidant enzyme regulation protects cells from hydrogen paroxide ${ }^{[19]}$. A comparison of first dimension IPG and 
NEPHGE techniques in two-dimensional gel electrophoresis experiment with cytosolic unfolded protein response in Saccharomyces cerevisiae ${ }^{[20]}$. In this study they compared IPG- based and NEPHGE based 2DE techniques by using the similar types of samples and they concluded that NEPHGE based method is most preferable over other methods [20]. Nevertheless, the narrow range ( $\mathrm{pH} 4-7)$ IPG technique is ideal for acidic proteins analysis. Another study of plant parasite Orobanche crenata and Pisum sativum revealed that metabolic and stress-related proteins play an important role during penetration and connection to the vascular system of the parasite ${ }^{[21]}$. However, due to low reproducibility 2-DE is criticised when comparative analysis of two different gels is performed ${ }^{[22,23]}$. There are, however, also some advance genomics techniques available for identification of pathogenesis related proteins from pathogen. The similar study of Athelia rolfsii genome indicates that there are several genes responsible for pathogenicity [24]. Nevertheless, advancements in plant-pathogen interactions through model plants become recent trend to apply similar approach in crop plants and help to improve agricultural practices with elite fungicide development in particular crop ${ }^{[25]}$. The proteomics study of chickpea may provide putative information about protein level regulation during chickpea and wilt disease interaction. Further, functional characterization will help to improve crop variety and other disease resistant traits.

\section{Conclusion}

The wilt disease in chickpea showed considerable proteomic changes during chickpea-wilt interaction. There are significant differences among wilt resistant and susceptible chickpea. There are also some up and down regulated proteins with reference to volume and coefficient of variation. This shows importance of proteomics techniques to determine proteins regulation during host pathogen interaction which helps to identify some putative proteins to identify some disease resistance proteins involved during infection.

\section{Acknowledgement}

The authors are extremely grateful to the Department of Biotechnology, JAU, Junagadh, India for the support and facilitation for carrying out the research work and Pulse research station, JAU, Junagadh, India for providing chickpea genotypes.

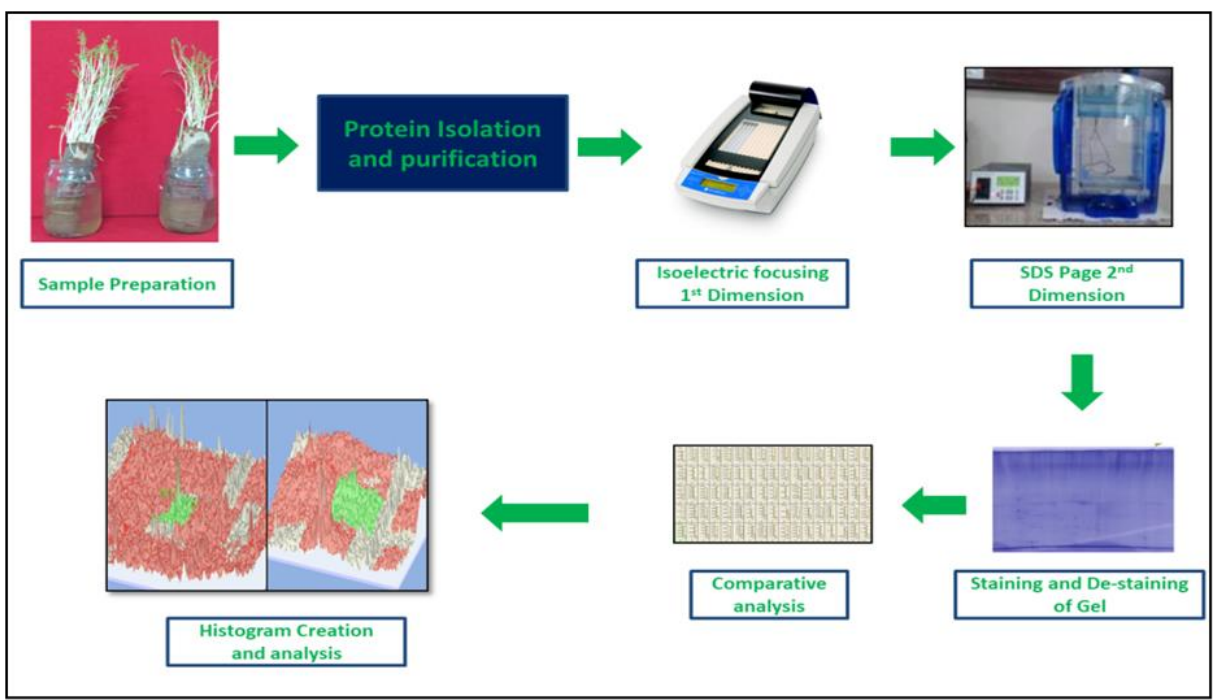

Fig 1: Graphical representation of chickpea-wilt protein profiling using two dimensional gel electrophoresis

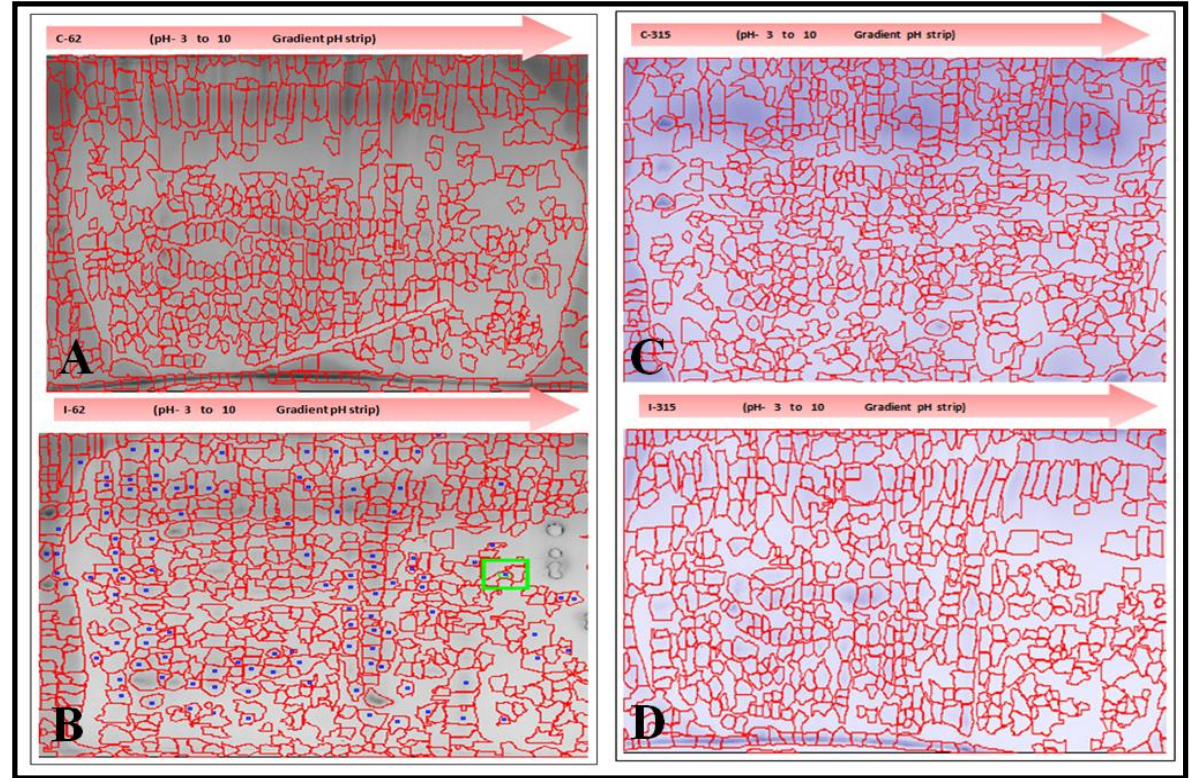

Fig 2: Root proteome profiling of control and F. oxysporum f.sp. ciceri (foc) infected chickpea genotypes JG62 (A, B); WR315 (C, D); (C= Control; I=Infected) 


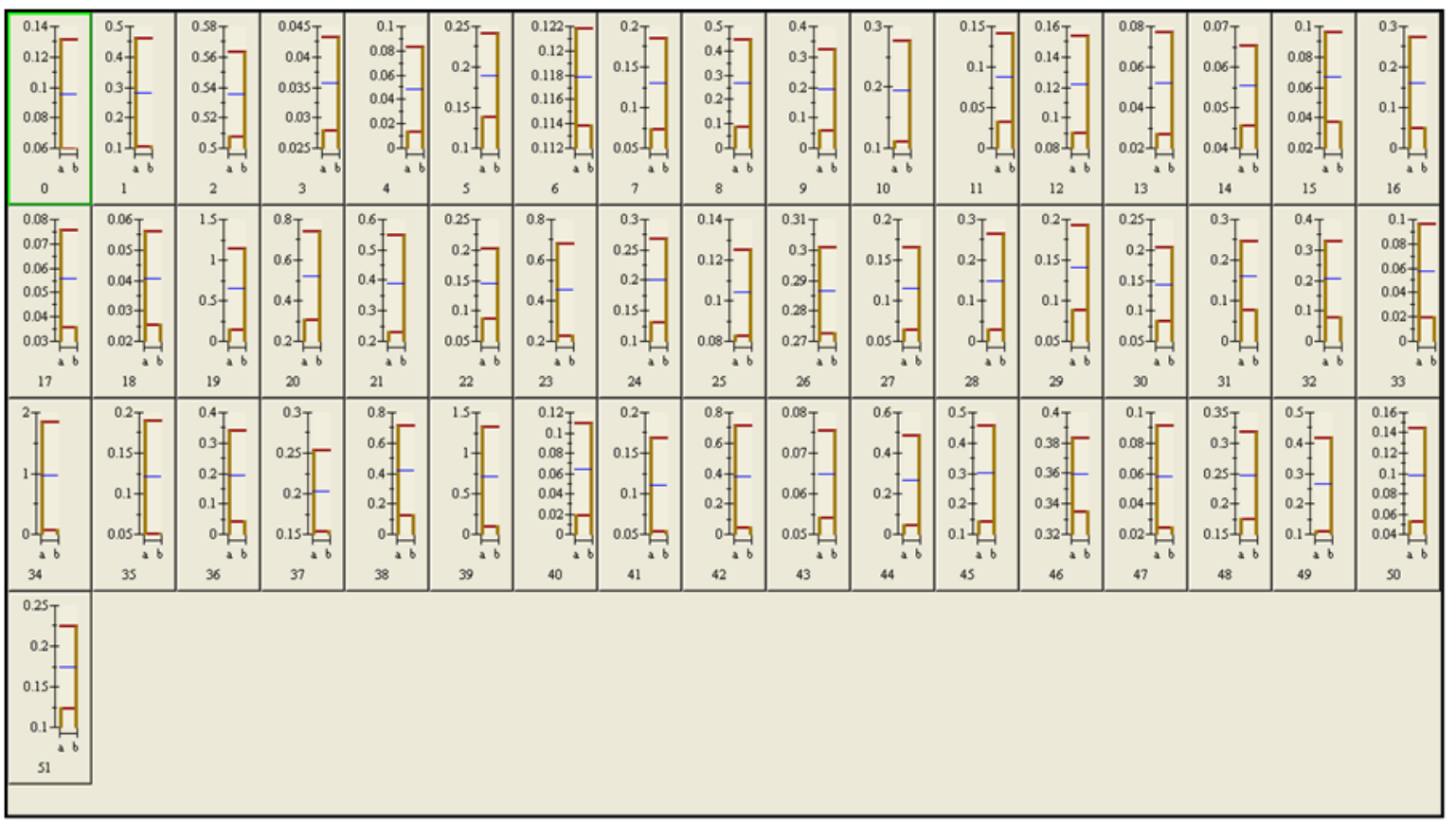

Fig 3: Comparative Histogram of Match ID spots, (a) C-62 (b)I-62 wilt susceptible chickpea genotypes

\begin{tabular}{|c|c|c|c|c|c|c|c|c|c|c|c|c|c|c|c|c|}
\hline ק. & 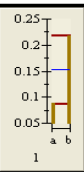 & 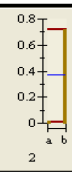 & $\begin{array}{c}0.2 \\
0.15- \\
0.1 \\
0.05 \\
0.05 \\
01 \\
0.5 \\
3\end{array}$ & ] & 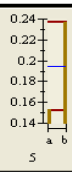 & $\begin{array}{c}0.08 \\
0.07 \\
0.07 \\
0.06 \\
0.05 \\
0.04 \\
0.04 \\
0.03\end{array}$ & 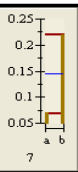 & - & 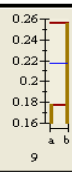 & 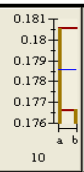 & 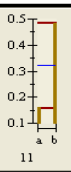 & 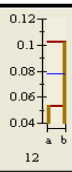 & ב & 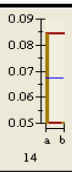 & $\begin{array}{l}0.08 \\
0.06 \\
0.04 \\
0.04 \\
0.02 \\
15 \\
15\end{array}$ & 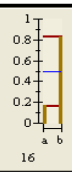 \\
\hline $\begin{array}{c}0.095 \\
0.09 \\
0.085 \\
0.7- \\
17\end{array}$ & ביב & $\begin{array}{c}0.4 \mathbb{L}^{2} \\
19^{6}\end{array}$ & 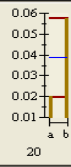 & $\begin{array}{l}0.07 \\
0.06 \\
0.05 \\
0.05 \\
0.04 \\
0.03 \\
0.03 \\
21 \\
2.6\end{array}$ & $\begin{array}{c}0.25 \\
0.25 \\
0.15 \\
0.1 \\
0.1 \\
0.05 \\
0.51 \\
22\end{array}$ & $\begin{array}{c}0.4 \\
0.3 \\
0.2 \\
0.2 \\
0.1 \\
0.1 \\
0.1 \\
23 \\
23 \\
23\end{array}$ & 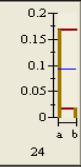 & $\begin{array}{c}c_{0.1}^{0.1} \bar{T} \\
0.08 \\
0.06 \\
0.04 \\
0.04 \\
0.02 \\
25 \\
25\end{array}$ & 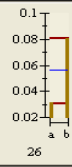 & 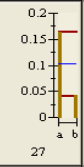 & $\begin{array}{c}0.16 \\
0.15 \\
0.14 \\
0.14 \\
0.13 \\
0.12 \\
0.12 \\
0.11 \\
28 \\
28\end{array}$ & $\begin{array}{c}0.22 \\
0.2 \\
0.18 \\
0.18 \\
0.16 \\
0.14 \\
0.12 \\
0.17 \\
29 \\
29\end{array}$ & ${ }_{30}^{01}$ & $\begin{array}{c}0.2 \mathrm{~T} \\
0.15 \\
0.1 \\
0.05 \\
0.05 \\
01 \\
31\end{array}$ & ב & $\begin{array}{c}0.055 \\
0.05 \\
0.045 \\
0.045 \\
0.035\end{array}$ \\
\hline $\begin{array}{c}0.06 \\
0.04 \\
0.02 \\
34\end{array}$ & $\begin{array}{l}0.08 \mathrm{~T} \\
0.07 \\
0.06 \\
0.06 \\
0.05 \\
0.04 \\
0.03 \\
0.03 \\
35 \\
35\end{array}$ & $\begin{array}{l}0.06 \\
0.05 \\
0.04 \\
0.04 \\
0.03 \\
0.02 \\
0.02 \\
36 \\
36\end{array}$ & 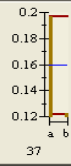 & $\begin{array}{c}0.14 \\
0.12 \\
0.12 \\
0.17 \\
0.08 \\
0.0 .7 \\
0.04 \\
0.04 \\
38 \\
38\end{array}$ & 年 & $\begin{array}{c}0.14 \mathrm{~T} \\
0.12 \\
0.1 \\
0.08 \\
0.08 \\
0.06 \\
0.04 \\
0.72 \\
40 \\
40\end{array}$ & 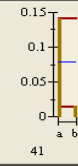 & ר. & ר. & 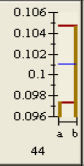 & $\begin{array}{l}{ }^{0.06} \\
{ }_{0.05}^{0.05} \\
0.04 \\
0.03 \\
0.03 \\
45\end{array}$ & $\begin{array}{c}0.13 \\
0.12 \\
0.11 \\
0.11 \\
0.1 \\
0.09 \\
0.08 \\
0.08 \\
46 \\
46\end{array}$ & $\begin{array}{c}0.1 \\
0.095 \\
47 \\
47\end{array}$ & $\begin{array}{c}0^{0.07} \mathrm{~T} \\
0.065=- \\
0.06-5 \\
0.055-1-1 \\
48\end{array}$ & $\begin{array}{c}0^{0.2} \\
0.15 \\
0.1 \\
0.05 \\
0.05 \\
01 \\
0.1 \\
{ }_{49}^{\circ}\end{array}$ & $\begin{array}{c}0.4 \\
0.3 \\
0.3 \\
0.2 \\
0.1 \\
0.1 \\
0.1 \\
\text { so } \\
\text { so }\end{array}$ \\
\hline $\begin{array}{c}0.11 \\
{ }_{51}\end{array}$ & $\begin{array}{c}0.092 \\
0.091 \\
0.09 \\
0.089 \\
0.089 \\
0.088 \\
52\end{array}$ & 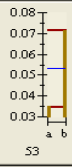 & 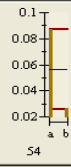 & ] & $\begin{array}{c}0.032 \\
0.039 \\
0.028 \\
0.028 \\
0.0229 \\
0.024 \\
0.0221 \\
56 \\
56\end{array}$ & $\begin{array}{c}0.18 \\
0.17 \\
0.16 \\
0.16 \\
0.15 \\
57 \\
57 \\
2\end{array}$ & $\begin{array}{c}0.08 \\
0.06 \\
0.04 \\
0.02 \\
0.02 \\
0.1 \\
58 \\
58\end{array}$ & בי & ] & 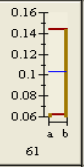 & $\begin{array}{c}0.3 \\
0.25 \\
0.2 \\
0.25 \\
0.15 \\
0.1 \\
0.1 \\
62 \\
62\end{array}$ & 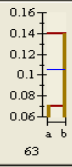 & 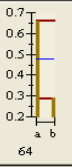 & $\begin{array}{c}0.041 \\
0.04 \\
0.039 \\
0.038 \\
0.5\end{array}$ & $\left.\left.\begin{array}{c}{ }^{0.2} \\
0.15 \\
0.1\end{array}\right]-7\right]$ & $\begin{array}{c}0.12 \\
0.1 \\
0.08 \\
0.06 \\
0.06 \\
0.04 \\
0.04 \\
67 \\
67\end{array}$ \\
\hline $\begin{array}{c}0.022 \\
0.22 \\
0.021 \\
0.016 \\
0.016 \\
0.014 \\
68 \\
6.4\end{array}$ & $\begin{array}{c}0.055 \\
0.05 \\
0.045 \\
0.04 \\
0.5 \\
69\end{array}$ & $\begin{array}{c}0.08 \mathrm{~T} \\
0.06 \\
0.04 \\
0.02 \\
0.02 \\
0.1-1\end{array}$ & 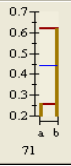 & ] & $\begin{array}{c}0.17-1 \\
0.08 \\
0.06= \\
0.04= \\
0.02 \\
0.1 \\
0.1 \\
73\end{array}$ & $\begin{array}{r}0.2 \mathrm{~T} \\
0.15 \\
0.1 \\
0.1 \\
0.05 \\
0.1\end{array}$ & 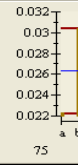 & $\begin{array}{c}0.2 \mathrm{~T} \\
0.18 \\
0.16 \\
0.16 \\
0.14 \\
0.12 \\
0.12 \\
0.1 \\
76 \\
76\end{array}$ & ] & $\left.\begin{array}{c}0.07 \\
0.06 \\
0.05 \\
0.05\end{array}\right]$ & $\begin{array}{l}0.4 \\
0.3 \\
0.2 \\
0.2 \\
0.1 \\
0.1 \\
0.1 \\
0.7 \\
79\end{array}$ & ב & (1) & $\begin{array}{c}0.429 \\
82\end{array}$ & $\begin{array}{c}0.09 \\
0.08 \\
0.07 \\
0.07 \\
0.06 \\
0.05 \\
83 \\
83\end{array}$ & 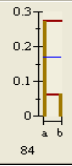 \\
\hline
\end{tabular}

Fig 4: Comparative Histogram of Match ID spots, (a) C-315 (b) I-315 wilt resistant chickpea genotypes

Table 1: Match ID of spots found in 2DE-Gel analysis of Chickpea genotype JG62

\begin{tabular}{|c|c|c|c|c|c|c|c|c|}
\hline \multirow{2}{*}{ Sr. No. } & \multirow{2}{*}{ Spot ID } & \multirow{2}{*}{ Coef. Variation } & \multicolumn{3}{|c|}{ Control } & \multicolumn{3}{|c|}{ Infection } \\
\cline { 4 - 9 } & & & \% volume & M.W. (K.Dal) & PI & \% volume & M.W. (K.Dal) & PI \\
\hline 1 & 0 & 0.47478 & 0.053674 & 29.0 & 5.58 & 0.15071 & 29.0 & 6.18 \\
\hline 2 & 1 & 0.42302 & 0.218546 & 29.0 & 5.14 & 0.08861 & 29.0 & 5.68 \\
\hline 3 & 2 & 0.95093 & 0.719361 & 29.0 & 5.38 & 0.01809 & 29.0 & 6.04 \\
\hline 4 & 3 & 0.57310 & 0.160510 & 29.0 & 5.22 & 0.04356 & 29.0 & 5.84 \\
\hline 5 & 4 & 0.08204 & 0.472728 & 29.0 & 5.39 & 0.40104 & 29.0 & 6.00 \\
\hline 6 & 5 & 0.21662 & 0.237257 & 29.0 & 5.50 & 0.15277 & 29.0 & 6.06 \\
\hline 7 & 6 & 0.37623 & 0.034524 & 29.0 & 5.27 & 0.07617 & 29.0 & 5.81 \\
\hline 8 & 7 & 0.51219 & 0.219470 & 29.0 & 4.71 & 0.07080 & 29.0 & 5.22 \\
\hline 9 & 8 & 0.34001 & 0.386180 & 29.0 & 4.32 & 0.19021 & 29.0 & 4.88 \\
\hline 10 & 9 & 0.17991 & 0.256343 & 29.0 & 4.96 & 0.17817 & 29.0 & 5.46 \\
\hline 11 & 10 & 0.01083 & 0.176666 & 29.0 & 4.73 & 0.18053 & 29.0 & 5.33 \\
\hline 12 & 11 & 0.50666 & 0.485666 & 29.0 & 4.19 & 0.15903 & 29.0 & 4.78 \\
\hline 13 & 12 & 0.31347 & 0.102228 & 29.0 & 5.13 & 0.05343 & 29.0 & 5.64 \\
\hline 14 & 13 & 0.59158 & 0.071014 & 29.0 & 4.68 & 0.27674 & 29.0 & 5.21 \\
\hline 15 & 14 & 0.25071 & 0.050599 & 29.0 & 5.25 & 0.08446 & 29.0 & 5.75 \\
\hline 16 & 15 & 0.47144 & 0.073231 & 29.0 & 5.41 & 0.02631 & 29.0 & 5.96 \\
\hline
\end{tabular}




\begin{tabular}{|l|l|l|l|l|l|l|l|l|}
\hline 17 & 16 & 0.66162 & 0.826583 & 29.0 & 4.18 & 0.16833 & 29.0 & 4.73 \\
\hline 18 & 17 & 0.07048 & 0.101004 & 29.0 & 4.56 & 0.08770 & 29.0 & 5.08 \\
\hline 19 & 18 & 0.75705 & 0.038746 & 29.0 & 4.81 & 0.28021 & 29.0 & 5.31 \\
\hline 20 & 19 & 0.18314 & 0.400494 & 29.0 & 5.15 & 0.58008 & 29.0 & 5.64 \\
\hline 21 & 20 & 0.48635 & 0.057683 & 29.0 & 5.55 & 0.01993 & 29.0 & 5.98 \\
\hline 22 & 21 & 0.32072 & 0.063101 & 29.0 & 5.50 & 0.03245 & 29.0 & 5.94 \\
\hline 23 & 22 & 0.54636 & 0.061782 & 29.0 & 4.64 & 0.21060 & 29.0 & 5.18 \\
\hline 24 & 23 & 0.86071 & 0.024796 & 29.0 & 5.26 & 0.33123 & 29.0 & 5.67 \\
\hline 25 & 24 & 0.80414 & 0.018271 & 29.0 & 5.33 & 0.16830 & 29.0 & 5.78 \\
\hline 26 & 25 & 0.45917 & 0.031981 & 29.0 & 5.39 & 0.08628 & 29.0 & 5.89 \\
\hline 27 & 26 & 0.43549 & 0.080577 & 29.0 & 5.06 & 0.03169 & 29.0 & 5.51 \\
\hline 28 & 27 & 0.59467 & 0.041509 & 29.0 & 5.97 & 0.16331 & 25.3 & 6.46 \\
\hline 29 & 28 & 0.15275 & 0.111509 & 29.0 & 4.74 & 0.15172 & 29.0 & 5.23 \\
\hline 30 & 29 & 0.23071 & 0.135293 & 29.0 & 6.17 & 0.21644 & 30.0 & 6.66 \\
\hline 31 & 30 & 0.77108 & 0.336100 & 29.0 & 4.89 & 0.04344 & 29.0 & 5.34 \\
\hline 32 & 31 & 0.55964 & 0.047030 & 29.0 & 4.56 & 0.16657 & 29.0 & 5.05 \\
\hline 33 & 32 & 0.13690 & 0.055556 & 29.0 & 4.19 & 0.07318 & 29.0 & 4.68 \\
\hline 34 & 33 & 0.17751 & 0.050219 & 29.0 & 4.83 & 0.03508 & 29.0 & 5.31 \\
\hline 35 & 34 & 0.35935 & 0.079911 & 29.0 & 4.96 & 0.03766 & 29.0 & 5.42 \\
\hline 36 & 35 & 0.35470 & 0.036677 & 29.0 & 4.20 & 0.07700 & 29.0 & 4.66 \\
\hline 37 & 36 & 0.36337 & 0.052555 & 29.0 & 4.30 & 0.02454 & 29.0 & 4.74 \\
\hline 38 & 37 & 0.23234 & 0.122552 & 29.0 & 4.76 & 0.19674 & 29.0 & 5.23 \\
\hline 39 & 38 & 0.49251 & 0.041916 & 29.0 & 5.90 & 0.12328 & 29.0 & 6.34 \\
\hline 40 & 39 & 0.43074 & 0.065700 & 29.0 & 5.99 & 0.16512 & 31.7 & 6.40 \\
\hline 41 & 40 & 0.49589 & 0.045293 & 29.0 & 5.77 & 0.13440 & 26.9 & 6.22 \\
\hline 42 & 41 & 0.80545 & 0.015216 & 29.0 & 5.70 & 0.14121 & 29.0 & 6.16 \\
\hline 43 & 42 & 0.06721 & 0.332204 & 29.0 & 4.33 & 0.29036 & 29.0 & 4.73 \\
\hline 44 & 43 & 0.16202 & 0.043058 & 29.0 & 5.78 & 0.05971 & 30.9 & 6.21 \\
\hline 45 & 44 & 0.03587 & 0.104652 & 29.0 & 5.90 & 0.09740 & 35.5 & 6.30 \\
\hline
\end{tabular}

Table 2: Match ID of spots found in 2DE-Gel analysis of Chickpea genotype WR315

\begin{tabular}{|c|c|c|c|c|c|c|c|c|}
\hline \multirow{2}{*}{ Sr. No. } & \multirow{2}{*}{ Spot ID } & \multirow{2}{*}{ Coef. Variation } & \multicolumn{3}{|c|}{ Control } & \multicolumn{3}{|c|}{ Infection } \\
\hline & & & $\%$ volume & M.W. (K.Dal) & PI & \% volume & M.W. (K.Dal) & PI \\
\hline 1 & 0 & 0.36990 & 0.060251 & 29.0 & 5.58 & 0.130991 & 29.0 & 6.18 \\
\hline 2 & 1 & 0.61800 & 0.108413 & 29.0 & 5.14 & 0.459193 & 29.0 & 5.68 \\
\hline 3 & 2 & 0.05093 & 0.562904 & 29.0 & 5.38 & 0.508341 & 29.0 & 6.04 \\
\hline 4 & 3 & 0.21412 & 0.043253 & 29.0 & 5.22 & 0.027997 & 29.0 & 5.84 \\
\hline 5 & 4 & 0.70492 & 0.082800 & 29.0 & 5.39 & 0.014331 & 29.0 & 6.00 \\
\hline 6 & 5 & 0.26604 & 0.240689 & 29.0 & 5.50 & 0.139534 & 29.0 & 6.06 \\
\hline 7 & 6 & 0.03345 & 0.113958 & 29.0 & 5.27 & 0.121846 & 29.0 & 5.81 \\
\hline 8 & 7 & 0.42300 & 0.184536 & 29.0 & 4.71 & 0.074826 & 29.0 & 5.22 \\
\hline 9 & 8 & 0.65299 & 0.442258 & 29.0 & 4.32 & 0.092844 & 29.0 & 4.88 \\
\hline 10 & 9 & 0.68374 & 0.324130 & 29.0 & 4.96 & 0.060881 & 29.0 & 5.46 \\
\hline 11 & 10 & 0.42106 & 0.275641 & 29.0 & 4.73 & 0.112296 & 29.0 & 5.33 \\
\hline 12 & 11 & 0.61999 & 0.141521 & 29.0 & 4.19 & 0.033198 & 29.0 & 4.78 \\
\hline 13 & 12 & 0.25936 & 0.153779 & 29.0 & 5.13 & 0.090438 & 29.0 & 5.64 \\
\hline 14 & 13 & 0.47939 & 0.076814 & 29.0 & 4.68 & 0.027032 & 29.0 & 5.21 \\
\hline 15 & 14 & 0.17496 & 0.065171 & 29.0 & 5.25 & 0.045762 & 29.0 & 5.75 \\
\hline 16 & 15 & 0.43807 & 0.037500 & 29.0 & 5.41 & 0.095969 & 29.0 & 5.96 \\
\hline 17 & 16 & 0.68652 & 0.050736 & 29.0 & 4.18 & 0.272957 & 29.0 & 4.73 \\
\hline 18 & 17 & 0.34963 & 0.036240 & 29.0 & 4.56 & 0.075204 & 29.0 & 5.08 \\
\hline 19 & 18 & 0.37201 & 0.025579 & 29.0 & 4.81 & 0.055883 & 29.0 & 5.31 \\
\hline 20 & 19 & 0.76292 & 1.137340 & 29.0 & 5.15 & 0.152949 & 29.0 & 5.64 \\
\hline 21 & 20 & 0.40976 & 0.736722 & 29.0 & 5.55 & 0.30845 & 29.0 & 5.98 \\
\hline 22 & 21 & 0.40655 & 0.547662 & 29.0 & 5.50 & 0.231071 & 29.0 & 5.94 \\
\hline 23 & 22 & 0.38922 & 0.201341 & 29.0 & 4.64 & 0.08852 & 29.0 & 5.18 \\
\hline 24 & 23 & 0.49420 & 0.230144 & 29.0 & 5.26 & 0.679875 & 29.0 & 5.67 \\
\hline 25 & 24 & 0.33780 & 0.268553 & 29.0 & 5.33 & 0.132932 & 29.0 & 5.78 \\
\hline 26 & 25 & 0.20154 & 0.125027 & 29.0 & 5.39 & 0.083083 & 29.0 & 5.89 \\
\hline 27 & 26 & 0.04889 & 0.272672 & 29.0 & 5.06 & 0.300703 & 29.0 & 5.51 \\
\hline 28 & 27 & 0.43330 & 0.165268 & 29.0 & 5.97 & 0.065344 & 25.3 & 6.46 \\
\hline 29 & 28 & 0.79276 & 0.264169 & 29.0 & 4.74 & 0.030537 & 29.0 & 5.23 \\
\hline 30 & 29 & 0.36310 & 0.191689 & 29.0 & 6.17 & 0.089566 & 30.0 & 6.66 \\
\hline 31 & 30 & 0.41712 & 0.203171 & 29.0 & 4.89 & 0.083567 & 29.0 & 5.34 \\
\hline 32 & 31 & 0.51602 & 0.078153 & 29.0 & 4.56 & 0.244805 & 29.0 & 5.05 \\
\hline 33 & 32 & 0.60583 & 0.080758 & 29.0 & 4.19 & 0.329008 & 29.0 & 4.68 \\
\hline 34 & 33 & 0.65868 & 0.019760 & 29.0 & 4.83 & 0.096024 & 29.0 & 5.31 \\
\hline 35 & 34 & 0.91138 & 0.085629 & 29.0 & 4.96 & 1.84695 & 29.0 & 5.42 \\
\hline
\end{tabular}




\begin{tabular}{|l|l|l|l|l|l|l|l|l|}
\hline 36 & 35 & 0.57471 & 0.051299 & 29.0 & 4.20 & 0.189942 & 29.0 & 4.66 \\
\hline 37 & 36 & 0.77212 & 0.043900 & 29.0 & 4.30 & 0.341398 & 29.0 & 4.74 \\
\hline 38 & 37 & 0.23880 & 0.155052 & 29.0 & 4.76 & 0.252338 & 29.0 & 5.23 \\
\hline 39 & 38 & 0.69637 & 0.127547 & 29.0 & 5.90 & 0.712587 & 29.0 & 6.34 \\
\hline 40 & 39 & 0.85112 & 0.106321 & 29.0 & 5.99 & 1.32197 & 31.7 & 6.40 \\
\hline
\end{tabular}

\section{References}

1. Varshney RK, Song C, Saxena RK, Azam S, Yu S, Sharpe AG et al., Draft genome sequence of chickpea (Cicer arietinum) provides a resource for trait improvement, Nat. Biotechnol. 2013; 31:240-246.

2. Lichtenzveig J, Scheuring C, Dodge J, Abbo S, Zhang HB. Construction of BAC and BIBAC libraries and their applications for generation of SSR markers for genome analysis of chickpea, Cicer arietinum L. Theor. Appl. Genet. 2005; 110:492-510.

3. Singh R, Sharma P, Varshney RK, Sharma SK, Singh NK. Chickpea Improvement: Role of Wild Species and Genetic Markers. Biotechnol. Genet. Eng. Rev. 2008; 25:267-314.

4. Millan T, Winter P, Jüngling R, Gil J, Rubio J, Cho S, et al. A consensus genetic map of chickpea (Cicer arietinum L.) based on 10 mapping populations. Euphytica. 2010; 175:175-189.

5. Gaur PM, Jukanti AK, Varshney RK. Impact of Genomic Technologies on Chickpea Breeding Strategies. Agronomy. 2012; 2:199-221.

6. Padliya ND, Cooper B. Mass spectrometry-based proteomics for the detection of plant pathogens, Proteomics. 2006; 6:4069-4075.

7. Asano T, Makota K, Takumi N. The defense response in Arabidopsis thaliana against Fusarium sporotrichoides, Proteome Science. 2012; 10:61.

8. Carpentier SC, Panis B, Vertommen A, Swennen R, Sergeant K, Renaut J et al. Proteome analysis of nonmodel plants: a challenging but powerful approach, Mass Spectrom Rev. 2008; 27:354-377.

9. Gupta S, Chakraborti D, Rangi RK, Basu D, Das S. A molecular insight into the early events of chickpea (Cicer arietinum) and Fusarium oxysporum f. sp. ciceri (race 1) interaction through cDNA AFLP analysis, Phytopathology. 2009; 99:1245-1257.

10. Damerval C, de Vienne D, Zivy M, Thiellement H. Technical improvements in two-dimensional electrophoresis increase the level of genetic variation detected in wheat-seedling proteins, Electrophoresis, 1986; 7:52-54.

11. Jiang Q, Chen H, Pan X, Pan Q, Shi Y, Li X et al. Proteomic analysis of wheat (Triticum aestivum L.) hybrid necrosis, Plant Science. 2008; 175:394-401.

12. Han F, Chen H, Li XJ, Yang MF, Liu GS, Shen SH. A comparative proteomic analysis of rice seedling under various high temperature stresses, Biochemica et Biophysica Acta. 2009; 1794(11):1625-1634.

13. Sambrook J, Fritschi EF, Maniatis T. Molecular cloning: a laboratory manual, Cold Spring Harbor Laboratory Press, New York, 1989.

14. Chatterjee M, Gupta S, Bhar A, Chakraborti D, Basu1 D, Das S. Analysis of root proteome unravels differential molecular responses during compatible and incompatible interaction between chickpea (Cicer arietinum L.) and Fusarium oxysporum f. sp. ciceri Race1 (Foc1), BMC Genomics. 2014; 15:949.

15. Afzal AJ, Natarajan A, Saini N, Iqbal MJ, Geisler M, Shemy El HA et al. The Nematode Resistance Allele at the rhg1 Locus Alters the Proteome and Primary Metabolism of Soybean Roots, Plant Physiol. 2009; 151:1264-1280.

16. Chen X, Fu S, Zhang P, Gu Z, Liu J, Qian Q, Ma B. Proteomic analysis of a disease-resistance-enhanced lesion mimic mutant spotted leaf 5 in rice, Rice. 2013; 6:1.

17. El-Rabey HA, Al-Malki AL, Abulnaja KO, Rohde W. Proteome Analysis for Understanding Abiotic Stress (Salinity and Drought) Tolerance in Date Palm (Phoenix dactylifera L.). Int J Genomics. 2015. 407165.

18. Rollins JA, Habte E, Templer SE, Colby T, Schmidt J, Von Korff M. Leaf proteome alterations in the context of physiological and morphological responses to drought and heat stress in barley (Hordeum vulgare L.). J Exp. Bot. 2013; 64(11):3201-3212.

19. Nishikawa M, Hashida M, Takakura Y. Catalase delivery for inhibiting ROS-mediated tissue injury and tumor metastasis. Adv. Drug Del. Rev. 2009; 61:319-326.

20. Slibinskas R, Razanskas R, Zinkeviciute R, Ciplys E. Comparison of first dimension IPG and NEPHGE techniques in two-dimensional gel electrophoresis experiment with cytosolic unfolded protein response in Saccharomyces cerevisiae, Proteome Sci. 2013; 11(1):36.

21. Castillejo MA, Aparicio MF, Rubiales D. Proteomic analysis by two-dimensional differential in gel electrophoresis (2D DIGE) of the early response of Pisum sativum to Orobanche crenata, Journal of Experimental Botany. 2012; 63(1):107-119.

22. Ruebelt MC, Leimgruber NK, Lipp M, Reynolds TL, Nemeth MA Astwood JD et al. Application of twodimensional gel electrophoresis to interrogate alterations in the proteome of genetically modified crops. 1. Assessing analytical validation J Agric. Food Chem. 2006; 54:2154-2161.

23. Hunt S, Thomas MR, Sebastian LT, Pedersen SK, Harcourt RL, Sloane AJ et al. Optimal replication and the importance of experimental design for gel-based quantitative proteomics J Proteome Res. 2005; 4:809819.

24. Tomar RS, Iquebal MA, Parakhia MV, Singla D, Jaiswal S, Rathod VM et al. Draft whole genome sequence of groundnut stem rot fungus Athelia rolfsii revealing genetic architect of its pathogenicity and virulence Scientific reports. 2017; 7(1):5299.

25. Fernandez FJ, Carbu M, Rabie El-Akhal M, Garrido C, Gonzalez-Rodriguez VE, Cantoral JM. Development of proteomics-based fungicides: new strategies for environmentally friendly control of fungal plant diseases, Int. J Mol. Sci. 2011; 12:795-816. 